Case Reports
in Dermatology
Case Rep Dermatol 2021;13:417-421

DOI: $10.1159 / 000511535$
Published online: July 29, 2021

(c) 2021 The Author(s)

Published by S. Karger AG, Basel www.karger.com/cde

This article is licensed under the Creative Commons Attribution-NonCommercial 4.0 International License (CC BY-NC) (http://www.karger.com/Services/OpenAccessLicense). Usage and distribution for commercial purposes requires written permission.

\title{
Sirolimus in the Management of Blue Rubber Bleb Nevus Syndrome: A Case Report and Review of the Literature
}

\author{
Bayan Musaed AINooh ${ }^{a} \quad$ Nada Ghazi AlQadrib Muhtadi Alghubayn ${ }^{c}$ \\ Saad Mohammed AlAjlan ${ }^{d}$ \\ aDepartment of Dermatology, King Saud University and King Khalid University Hospital, \\ Riyadh, Saudi Arabia; 'bepartment of Dermatology, King Saud Medical City, Riyadh, \\ Saudi Arabia; 'Department of Medicine, King Saud Medical City, Riyadh, Saudi Arabia; \\ dDepartment of Dermatology, King Faisal Specialist Hospital and Research Center, \\ Riyadh, Saudi Arabia
}

\section{Keywords}

Blue rubber bleb nevus syndrome $\cdot$ BRBNS $\cdot$ Sirolimus $\cdot$ Vascular malformation

\section{Abstract}

Blue rubber bleb nevus syndrome (BRBNS) is a rare multifocal venous malformation (VM) that may affect any tissue or organ but mainly affects the skin, subcutaneous tissue and gastrointestinal $(\mathrm{Gl})$ tract. Patients present with serious anemia, treated with lifelong iron supplements and frequent blood transfusion secondary to chronic Gl bleeding. Variable therapeutic modalities were used in the management of BRBNS; sirolimus (SRL), a mammalian target of rapamycin (mTOR) inhibitor, is found to be a promising therapy for vascular anomalies. 


\section{Case Reports in Dermatology}

Case Rep Dermatol 2021;13:417-421

DOI: $10.1159 / 000511535$

(c) 2021 www.karger.com/cde

AlNooh et al.: Sirolimus in the Management of Blue Rubber Bleb Nevus Syndrome: A Case Report and Review of the Literature

\section{Introduction}

Blue rubber bleb nevus syndrome (BRBNS) is a rare multifocal venous malformation (VM) that may affect any tissue or organ, but mainly affects the skin, subcutaneous tissue and gastrointestinal (GI) tract. BRBNS might present at birth (30\%), infancy (9\%) or early childhood (48\%) [1-3]. The syndrome is sometimes called Bean syndrome, after William Bean, who in 1958 was the first to characterize the lesions as compressible blue or purple cutaneous lesions with a diameter of 1-2 $\mathrm{cm}^{2}$ that are asymptomatic and rarely bleed spontaneously but bleed easily upon trauma $[4,5]$. Patients with BRBNS can develop coagulopathy with low fibrinogen and high D-dimer. In addition, they present with serious anemia, which can be treated with lifelong iron supplements and frequent blood transfusions secondary to chronic GI bleeding [1-3]. Some reported cases of BRBNS showed an autosomal dominant pattern of inheritance [6, 7], but most cases are sporadic. Variable therapeutic modalities are used in the management of BRBNS, including antiangiogenic agents such as corticosteroids and interferon-alpha, octreotide, sclerotherapy and aggressive surgery [1, 2, 5, 8-11]. According to multiple case reports, sirolimus (SRL), a mammalian target of the rapamycin (mTOR) inhibitor [1], has been found to be a promising therapy for vascular anomalies. Herein, we report the first Middle Eastern case in the literature: a patient with BRBNS that was successfully treated with sirolimus after the failure of several modalities of management.

\section{Case Presentation}

Our patient is an 18-year-old female who visited King Faisal Specialist Hospital and Research Center in 2004, where she was diagnosed with BRBNS involving the gastrointestinal tract, brain and skin. Her condition has been managed for many years with multiple modalities, including medical as well as chemotherapy (cyclosporine and vincristine) and interventional radiology performed by pediatric hematology oncology and radiology teams. Unfortunately, these measures failed to control her disease. In addition, because of gastrointestinal (GI) bleeding, the patient developed chronic anemia and since that time has been transfusion dependent on an almost weekly basis with no improvement of her hemoglobin. She would always present with low readings of WBC $\left(2.0-3.8 \times 10^{9} / / \mathrm{L}\right)$, RBC $\left(1.1-2.1 \times 10^{12} / \mathrm{L}\right)$, hemoglobin $(31-55 \mathrm{~g} / \mathrm{L})$ and platelets $\left(112-140 \times 10^{9} / \mathrm{L}\right)$.

In 2012, the patient travelled abroad where she had multiple surgical procedures, including surgical resection, laser and sclerotherapy of GI lesions, that resulted in complete control of her disease with no requirement of blood transfusions since. Part of her preventive management plan was sirolimus $1 \mathrm{mg}\left(0.7 \mathrm{mg} / \mathrm{m}^{2} /\right.$ day $) \mathrm{PO}$, which resulted in improvement of her lab readings: hemoglobin $(115 \mathrm{~g} / \mathrm{L}), \mathrm{RBC}\left(4.87 \times 10^{12} / \mathrm{L}\right)$, platelets $\left(176 \times 10^{9} / \mathrm{L}\right)$ and WBC $\left(4.21 \times 10^{9} / \mathrm{L}\right)$. Since 2012 , until her presentation to the dermatology clinic in 2017 , the patient has been on sirolimus $1 \mathrm{mg}$ PO daily.

However, the patient started to develop new lesions over her back and feet beginning 1 year prior. Therefore, in May 2017, when she visited the dermatology clinic, we adjusted the dose of sirolimus to $2 \mathrm{mg}\left(1.4 \mathrm{mg} / \mathrm{m}^{2} /\right.$ day). In subsequent follow-up visits, the patient's condition was improving with maintained hemoglobin and no development of new active lesions, except for low WBC $\left(3.16 \times 10^{9} / \mathrm{L}\right)$. Enhanced and non-enhanced magnetic resonance imaging (MRI) of the patient's head and neck were done in October 2017 and found that there was a

\section{Karger'=}




\section{Case Reports in Dermatology}

Case Rep Dermatol 2021;13:417-421

DOI: $10.1159 / 000511535$

c) 2021 The Author(s). Published by S. Karger AG, Basel www.karger.com/cde

AINooh et al.: Sirolimus in the Management of Blue Rubber Bleb Nevus Syndrome: A Case Report and Review of the Literature

4-cm decrease in the size of the lesion on her lower left neck in comparison to her last MRI done in 2010.

\section{Discussion}

BRBNS is a rare vascular anomaly syndrome characterized by multifocal lesions consisting of venous malformations, which appear prominently in the GI tract, skin and soft tissues $[1,2]$. As the patient grows, the number and size of lesions tend to increase [12]. One of the persistent complications of BRBNS is iron deficiency anemias due to chronic bleeding from GI lesions, which patients commonly experience at an early age. Therefore, patients require lifelong iron replacement, and in severe cases, regular blood transfusions might be required because of chronic anemias. This was true in our case, in which the patient had very low hemoglobin (31-55 g/L) and was thus receiving PRBC on a weekly basis.

Octreotide has been used in BRBNS, resulting in an improvement of symptoms with a decrease in transfusions over 12 months of follow-up, but repeated video capsule endoscopy revealed one case with no changes in the number and size of lesions [13]. Antiangiogenic agents, such as steroids, interferon-alpha and propranolol, were used, but the lesions failed to reduce in size and number when steroids were used alone. Furthermore, when steroids and interferon-alpha were used together, the lesions regrew after treatment was discontinued [13-15]. No convincing evidence has been reported for long-lasting effects from any pharmacological treatment. Laser photocoagulation and endoscopic removal have been tried, but without lifelong success [16]. Surgical removal is another modality of bleeding management in BRBNS, but it has been discouraged because of its aggressiveness and the probability that the excised lesions would regrow [2].

Sirolimus is a mammalian target of the rapamycin (mTOR) inhibitor. mTOR is a protein complex that contributes to several cellular processes, such as cell growth, cell survival and angiogenesis. Additionally, it has potent antineoplastic and immunosuppressive properties [17]. With our patient, hemoglobin levels normalized after starting sirolimus, with no need for further blood transfusions. We observed no adverse effects, such as hyperlipidemia, mucositis, diarrhea, hepatic damage, azotemia, proteinuria, anemia, thrombocytopenia, and recurrent or severe systemic infection [18], except for neutropenia.

The first published case report of sirolimus in the treatment of BRBNS was in 2012; it demonstrated the efficacy of sirolimus at low doses to treat skin lesions and reduce GI bleeding after the failure of numerous management modalities [16]. In the past few years, multiple cases of BRBNS managed with sirolimus were reported to exhibit positive effects $[1,12,16-$ 19].

To our knowledge, our case represents the first case in the Middle East to show the efficacy of sirolimus in treating chronic iron deficiency anemia in BRBNS.

\section{Conclusion}

BRBNS is a rare multifocal VM that most commonly affects the skin, subcutaneous tissue and GI tract. Commonly used therapeutic modalities to treat BRBNS include corticosteroids, interferon-alpha, octreotide, sclerotherapy and aggressive surgery. However, these modalities often fail to produce long-lasting effects or are unfavorable due to their aggressive nature.

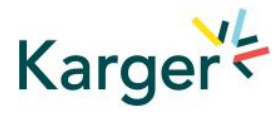




\section{Case Reports in Dermatology}

\begin{tabular}{l|l}
\hline Case Rep Dermatol 2021;13:417-421 \\
\hline DOI: 10.1159/000511535 & $\begin{array}{l}\text { C 2 2021 The Author(s). Published by S. Karger AG, Basel } \\
\text { www.karger.com/cde }\end{array}$ \\
\hline
\end{tabular}

AlNooh et al.: Sirolimus in the Management of Blue Rubber Bleb Nevus Syndrome: A Case Report and Review of the Literature

Herein, we conclude that sirolimus gives a promising response in treating BRBNS refractory to other treatment modalities and helps to avoid an aggressive surgical approach.

\section{Statement of Ethics}

A signed consent was provided by the patient to publish this case. The study protocol was approved by the institute's committee.

\section{Conflict of Interest Statement}

The authors have no conflicts of interest to declare.

\section{Funding Sources}

This research received no specific grant from any funding agency in the public, commercial, or not-for-profit sectors.

\section{Author Contributions}

Bayan Musaed Alnooh (writing of the manuscript), Nada Ghazi Alqadri (writing of the manuscript), Muhtadi Alghubayn (writing and editing of the manuscript) Saad Alajlan (writing and editing of the manuscript).

\section{References}

1 Salloum R, Fox CE, Alvarez-Allende CR, Hammill AM, Dasgupta R, Dickie BH, et al. Response of Blue Rubber Bleb Nevus Syndrome to Sirolimus Treatment. Pediatr Blood Cancer. 2016 Nov;63(11):1911-4.

2 Fishman SJ, Smithers CJ, Folkman J, Lund DP, Burrows PE, Mulliken JB, et al. Blue rubber bleb nevus syndrome: surgical eradication of gastrointestinal bleeding. Ann Surg. 2005 Mar;241(3):523-8.

3 Jin XL, Wang ZH, Xiao XB, Huang LS, Zhao XY. Blue rubber bleb nevus syndrome: a case report and literature review. World J Gastroenterol. 2014 Dec;20(45):17254-9.

4 Korekawa A, Nakajima K, Aizu T, Nakano H, Sawamura D. Blue Rubber Bleb Nevus Syndrome Showing Vascular Skin Lesions Predominantly on the Face. Case Rep Dermatol. 2015 Jul;7(2):194-8.

5 Chen W, Chen H, Shan G, Yang M, Hu F, Li Q, et al. Blue rubber bleb nevus syndrome: our experience and new endoscopic management. Medicine (Baltimore). 2017 Aug;96(33):e7792.

6 Walshe MM, Evans CD, Warin RP. Blue rubber bleb naevus. BMJ. 1966 Oct;2(5519):931-2.

7 Gallione CJ, Pasyk KA, Boon LM, Lennon F, Johnson DW, Helmbold EA, et al. A gene for familial venous malformations maps to chromosome 9p in a second large kindred. J Med Genet. 1995 Mar;32(3):197-9.

8 Adams DM, Trenor CC 3rd, Hammill AM, Vinks AA, Patel MN, Chaudry G, et al. Efficacy and Safety of Sirolimus in the Treatment of Complicated Vascular Anomalies. Pediatrics. 2016 Feb;137(2):e20153257.

9 Özgönenel B, Martin A. Low-dose sirolimus controls recurrent iron deficiency in a patient with blue rubber bleb nevus syndrome. Pediatr Blood Cancer. 2015 Nov;62(11):2054-5.

10 Ferrés-Ramis L, Knöpfel N, Salinas-Sanz JA, Martín-Santiago A. Rapamycin in the treatment of blue rubber bleb nevus syndrome [English Edition]. Actas Dermosifiliogr. 2015 Mar;106(2):137-8.

11 Li J, Kim SG, Blenis J. Rapamycin: one drug, many effects. Cell Metab. 2014 Mar;19(3):373-9.

12 Akyuz C, Susam-Sen H, Aydin B. Blue Rubber Bleb Nevus Syndrome: Promising Response To Sirolimus. Indian Pediatr. 2017 Jan;54(1):53-4.

\section{Karger'=}




\section{Case Reports in Dermatology}

13 Gonzalez D, Elizondo BJ, Haslag S, Buchanan G, Burdick JS, Guzzetta PC, et al. Chronic subcutaneous octreotide decreases gastrointestinal blood loss in blue rubber-bleb nevus syndrome. J Pediatr Gastroenterol Nutr. 2001 Aug;33(2):183-8.

14 Boente MD, Cordisco MR, Frontini MD, et al. Blue rubber bleb nevus (Bean syndrome): evolution of four cases and clinical response to pharmacologic agents. Pediatr Dermatol. 1999 May-Jun;16(3):222-27.

15 Shurafa M, Kamboj G. Thalidomide for the treatment of bleeding angiodysplasias. Am J Gastroenterol. 2003 Jan;98(1):221-2.

16 Yuksekkaya H, Ozbek O, Keser M, Toy H. Blue rubber bleb nevus syndrome: successful treatment with sirolimus. Pediatrics. 2012 Apr;129(4):e1080-4.

17 Warner B, Butt A, Cairns S. Sirolimus is a successful treatment for recurrent iron deficiency anaemia in blue rubber bleb naevus syndrome. J Pediatr Gastroenterol Nutr. 2015 Jun;60(6):e49-50.

18 Hammill AM, Wentzel M, Gupta A, Nelson S, Lucky A, Elluru R, et al. Sirolimus for the treatment of complicated vascular anomalies in children. Pediatr Blood Cancer. 2011 Dec;57(6):1018-24.

19 Menegozzo CA, Novo FD, Mori ND, Bernini CO, Utiyama EM. Postoperative disseminated intravascular coagulation in a pregnant patient with Blue Rubber Bleb Nevus Syndrome presenting with acute intestinal obstruction: case report and literature review. Int J Surg Case Rep. 2017;39:235-8. 